\title{
A romániai magyar nyelvjárások atlasza informatizált térképlapjainak kvantitatív nyelvföldrajzi vizsgálata*
}

1. Bevezetés. Lassan huszonöt éve, hogy fölmerült a magyar nyelvjárások kutatóinak körében az adatok számítógépes feldolgozásának, kutathatóvá tételének szükségessége (BALOGH-KISS 1992). A Bihalbocs elindulásával valóban lehetővé is vált régi atlaszaink hatékony, erőforrás-kímélö számítógépes feldolgozása, informatizálása, így téve nemcsak könnyebben kezelhetővé, hanem a papír változatnál összehasonlíthatatlanul sokrétübben felhasználhatóvá a bennük rejlö nyelvi adatokat (VÉKÁs 2007).

Mit „tud” egy informatizált nyelvjárási adat egy (akár digitálisan előállított) hagyományos, térképre rajzolt adathoz képest? Az informatizált nyelvi adatok sokoldalúan hasznosíthatók és újrahasznosíthatók: kereshetők, tetszőleges szempontok szerint térképezhetők, más, azonos elvek szerint rögzített adatokkal integrálhatók, számszerü kimutatások készíthetők belölük.

2005 és 2007 között egy NKFP finanszírozású projektben ${ }^{1}$ informatizáltuk A romániai magyar nyelvjárások atlasza (a továbbiakban: RMNyA.) 5-8. köteteit (összesen 1200 térképlapot). Dolgozatomban ezen informatizált adatok alapján vizsgálom a nyelvi hasonlóság mértékét az RMNyA. kutatópontjai között, dialektometriai térképek segítségével. Az elemzéshez olyan kutatópontokat választottam, amelyek a dialektológia tankönyv nyelvjárási régiókat ismertető fejezetei (JUHÁSZ 2001; BALOGH 2001), illetve PÉNTEK JÁNOS akadémiai székfoglalója (2005) alapján nyelv(járás)sziget helyzetünek mondhatók.

2. Kvantitatív nyelvföldrajz. A kvantitatív nyelvföldrajzi vizsgálatok lényege, hogy több száz térképlap adatait vizsgáljuk, előre meghatározott szempontok szerint, számszerüsítve a kutatópontok adatai közti összefüggéseket. Nem néhány, a kutató prekoncepciójával összhangban álló térképlapot vizsgálunk tehát, hanem több száz térképlapot (így akár több százezer vagy akár millió nyelvi adatot), válogatás nélkül. Így a kvantitatív elemzési módszerek más eljárásokhoz képest sokkal objektívebbnek mondhatók.

A meghatározás szerint kvantitatív nyelvföldrajzi vizsgálatnak tekinthetjük a hangstatisztikai térképeket, amelyek bizonyos hangok előfordulási gyakoriságát, arányát mutatják meg az egyes kutatópontokon, illetve az egyes kutatópontok között (1. pl. BODÓ-VARGHA 2008; JUHÁSZ 2011; VARGHA 2007a, 2013).

* Az Egy elkészült és egy készülő magyar nyelvatlasz - kutatási tapasztalatok és perspektívák címü konferencián 2011. november 23-án elhangzott előadás szerkesztett, bővített változata. A kutatást az OTKA PD 108442 számú pályázata támogatta. A szerző a dolgozat elkészítésekor Bolyai János Kutatási Ösztöndíjban részesült.

${ }^{1}$ A magyar nyelvváltozatok geolingvisztikai kutatása (A regionális nyelvi örökség gyüjtése, informatizálása és korpusznyelvészeti integrálása). A projekt száma: 5/056/2004.

Magyar Nyelv 112. 2016: 152-163. DOI: 10.18349/MagyarNyelv.2016.2.151 
Készíthetünk térképes kimutatást egy meghatározott korpuszban, a kutatói szempontok szerint kódolt jelenségek, nyelvi változók előfordulásáról is. Ilyen kimutatást készített BODÓ CSANÁD a moldvai csángó nyelvjárás atlaszában elöforduló román kölcsönszók területiségéről (BODÓ 2007). Nyelvi változók kódolására és térképezésére azonban nemcsak informatizált nyelvatlaszok, hanem területi szempontú szöveges adatbázisok felhasználásával is van lehetőség. Utóbbira példa A magyar nyelvjárások atlasza (a továbbiakban: MNyA.) szövegfelvételei alapján tett kísérlet a suksükölés hatvanas évekbeli területi elterjedtségének vizsgálatára a Dunántúlon (VARGHA 2007b).

A kvantitatív nyelvföldrajz talán legjellegzetesebb vizsgálati iránya a dialektometria, amelynek lényege (a fenti példáktól eltérően) nem egy-egy nyelvi változó elemzése, hanem egy nyelvatlasz (vagy annak legalább száz térképlapja) összes adatának kutatópontonkénti összevetése (VARGHA-VÉKÁs 2009; VARGHA 2015a, 2015b). A továbbiakban ezt az elemzési módot, illetve az RMNyA. anyagából az ezzel a módszerrel készült térképes elemzéseket mutatom be részletesebben.

3. Dialektometria. A dialektometria kifejezést JEAN SÉGUY francia dialektológus használta először az 1970-es években. Szomszédos kutatópontok megfelelő adatai közötti eltéréseket számszerüsített atlaszadatok alapján, és eszerint próbált nyelvjáráshatárokat megállapítani (SÉGUY 1973; idézi CHAMBERS-TRUDGILL 1998).

A szintén romanista HANS GOEBL már nem csak szomszédos kutatópontok adatait veti össze: egy atlasz minden kutatópontját minden más kutatópontjával egyenként egybeveti, egy hasonlósági mátrixot hozva létre. A mátrixból tehát bármely kutatópont bármely másik kutatóponthoz mért nyelvi hasonlóságának mértéke egy szám formájában kiolvasható. Ha egy szám a maximumhoz (mondjuk 100\%-hoz) közeli, a hasonlóság mértéke nagy, kisebb szám pedig értelemszerủen gyengébb hasonlóságot jelez. A különböző számokhoz pedig különböző színek társíthatók a térképes megjelenítés során (GOEBL 2006).

A groningeni egyetem kutatói, JOHN NERBONNE és WiLBERT HEERINGA, LEVENSHTEIN algoritmusát használva vetnek össze nyelvjárási adatokat, így nem kutatói döntések, csoportosítások, hanem egy matematikai eljárás segítségével hozva létre egy, a kutatópontok közti nyelvi hasonlóság mértékét megmutató mátrixot (HEERINGA 2004; NERBONNE-HEERINGA 2013). Az általam felhasznált térképes dialektometriai kimutatások is ehhez hasonló módszerrel készültek, vagyis LEVENSHTEIN algoritmusának használatán alapulnak. Az algoritmus két, fonetikusan lejegyzett és betüláncnak felfogott adat egymáshoz képest meghatározott távolságát méri (azaz a különbözőség mértékét fejezi ki számszerüsített formában). Ezzel a módszerrel - térképlaponként haladva - páronként összevetjük egymással egy nyelvatlasz kutatópontjainak adatait, mindig megállapítva a két adat közötti különbözőség (illetve hasonlóság) mértékét, akár több száz kutatópont és térképlap esetében. Az összevetések számszerüsített végeredménye egy hasonlósági mátrix, amely azt tükrözi, hogy átlagosan milyen arányban mutatnak hasonlóságot egymással az egyes kutatópontok adatai. Így bármelyik kutatópontról megállapíthatjuk, hogy adatai átlagosan mely kutatópontok adataival mutatnak nagyobb, és melyekkel kisebb hasonlóságot. (Saját magával értelemszerüen 
minden kutatópont esetében 100\%-os hasonlóság áll fenn.) Az RMNyA. 11 kötetéből eddig négy teljes kötet áll rendelkezésünkre megfelelő formában ahhoz, hogy dialektometriai elemzést készíthessünk belőle (ez 1200 térképlapot jelent). A dialektometriai kutatásokban minimumnak tekintett, és a hasonló kimutatásokhoz felhasznált 100 térképlapnyi adatmennyiségnél ez nagyságrendekkel nagyobb korpuszt, és ezáltal várhatóan sokkal pontosabb elemzést jelent.

Az RMNyA. különleges értéke a lejegyzés koherenciája, ugyanis az atlasz valamennyi adatát egyedüli gyüjtőként MURÁDIN LÁszLó jegyezte le. A finoman mellékjelezett adatok nagyban segíthetik az elemzéseinket, hiszen a hangárnyalatok (például a felhő szó első magánhangzójának lehetséges minőségei) jellemző területi megoszlást mutathatnak.

A lejegyzés informatizált változata arra is alkalmas, hogy szükség szerint konvertáljuk fonetikailag kevésbé pontos formába (eltüntetve például a mellékjeleket, akár eltekintve a magánhangzók közti minőségbeli különbségektől). A fonetikailag különböző finomságú adatok különböző arányokban mutatnak egyezéseket egymással. A felhö, a fëlhö és a fölhö (illetve ezek mellékjelezett vagy diftongusos változatai) például $100 \%$-os egyezést mutatnak egymással, ha a magánhangzók közti különbséget egy konverziós eljárás segítségével megszüntetjük. A homáj (és annak fonetikai variánsai) azonban még ekkor is jelentős mértékben különbözni fognak a felhö, fëlhö stb. adatoktól. Több hasonlósági mátrixot is készíthetünk a kutatópontjainkról aszerint, hogy milyen mértékben vesszük figyelembe a hangtani különbségeket (erről bővebben 1. VARGHA 2015b).

4. Dialektometriai térképek. Az RMNyA. következő kutatópontjainak nyelvi hasonlósági viszonyait vizsgáltam: Szabófalva, Bogdánfalva, Pusztina, Diószeg, Csernakeresztúr, Lozsád, Oltszakadát, Halmágy, Domokos, Köröstárkány és Végvár. A térképek azt mutatják meg, hogy a kijelölt (a kutatópont közepén fekete háromszöggel megjelölt) kutatóponttal mely atlaszbeli kutatópontok mutatnak leginkább nyelvi hasonlóságot. A kijelölt kutatóponthoz nyelvileg leginkább hasonlók fekete, a vele legkisebb mértékben hasonlóságot mutatók egészen halványszürke színnel látszanak. A két végpont között az egyre halványabb szürke színárnyalatok érzékeltetik az egyre kisebb fokú nyelvi hasonlóságot. (Az eredményeket összegzően az 1. táblázat mutatja be.)

A négy moldvai kutatópont közül Szabófalva (a további három moldvai kutatóponttól markánsan eltérően) az észak-mezőségi Mezőveresegyházával és Nyíressel mutat leginkább nyelvi hasonlóságot (1. térkép). A további három moldvai kutatópont (tehát a mezőségi alapú Bogdánfalva is) leginkább keleti székely településekkel rokonítható (2-4. térkép, a településeket név szerint 1. később, az 1. táblázatban). Itt jegyzem meg, hogy elemzésünk során nem szabad megfeledkeznünk arról, hogy itt csupán arra a 136 településre támaszkodhatunk, amelyek az RMNyA. gyüjtőpontjai voltak. Az itt bemutatott elemzés tehát nem mindig lehet pontos, az esetek többségében inkább irányokat, mint konkrét helyeket jelöl. Pontosabb elemzésre csak nagyobb sürüségü kutatópont-hálózattal készült adatfelvételek, jellemzően a kisebb regionális atlaszok adatai alapján volna lehetőségünk. 
1. térkép

Szabófalva

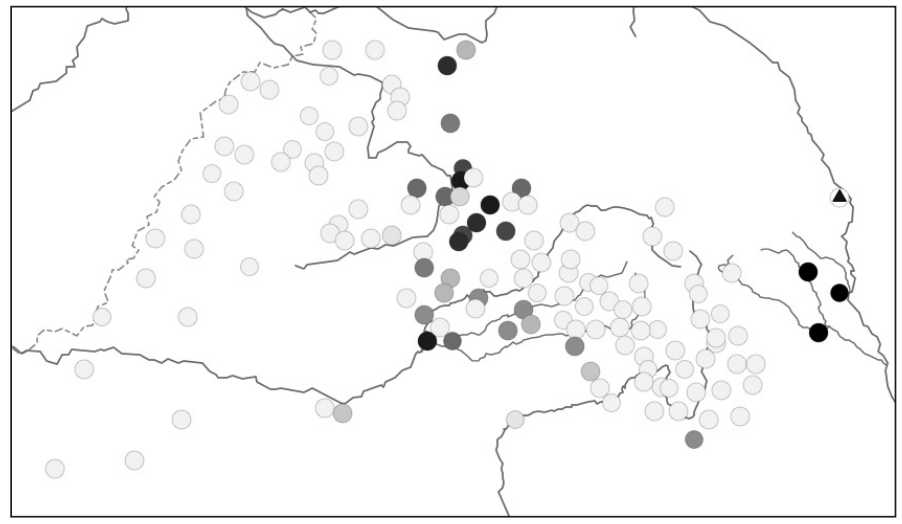

2. térkép

Bogdánfalva

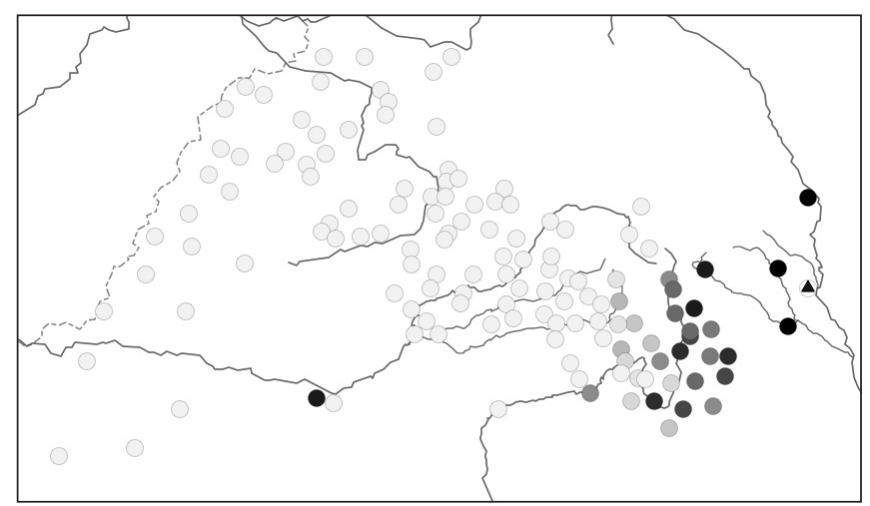

3. térkép

Pusztina

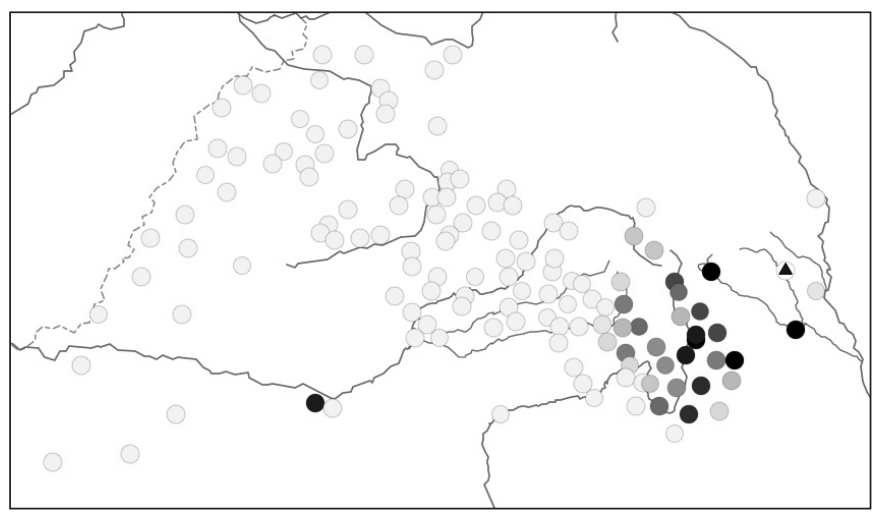




\section{4. térkép}

Diószeg

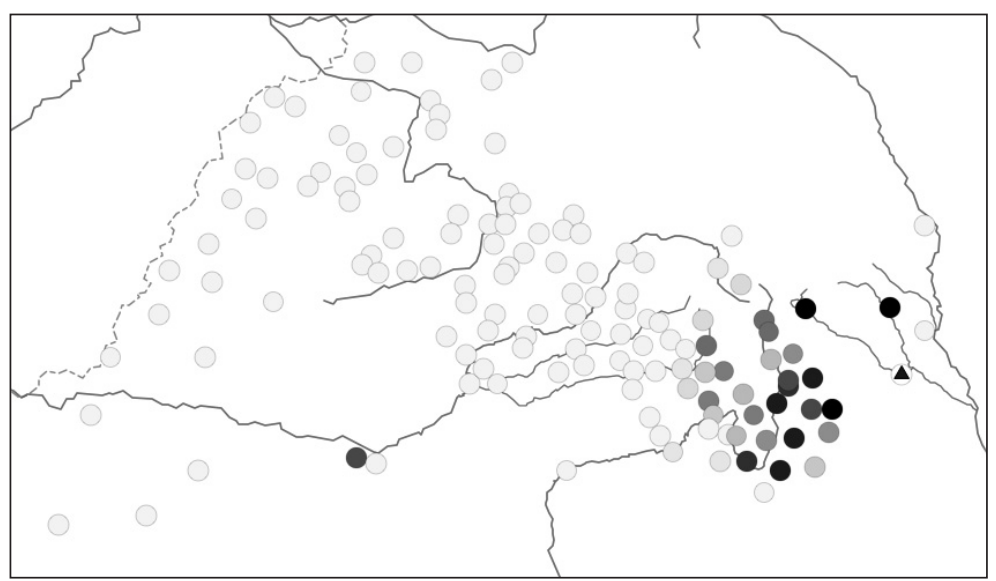

Két szomszédos kutatópont, Csernakeresztúr (5. térkép) és Lozsád (6. térkép) esetében igen látványosan eltér egymástól a nyelvi hasonlóság földrajzi súlypontja. Ha Csernakeresztúrra kattintunk az interaktív dialektometriai térképen, leginkább a Székelyföld keleti részén látunk fekete, illetve sötétszürke színnel felvillanó, tehát nagyobb nyelvi hasonlóságot jelző kutatópontokat. Ha azonban Lozsád a kijelölt kutatópont, a Mezőség déli részén látunk sötétebb árnyalatokat. Az, amit a dialektometria mutat, teljes összhangban van azzal, amit ezekről a kutatópontokról tudunk az eddigi dialektológiai kutatások alapján (JUHÁSZ 2001; PÉNTEK 2005). Csernakeresztúr bukovinai székely település, Lozsád pedig a Közép- és Felsö-Maros mentével, illetve a Küküllők vidékével mutat szorosabb nyelvi kapcsolatokat.

\section{5. térkép}

Csernakeresztúr

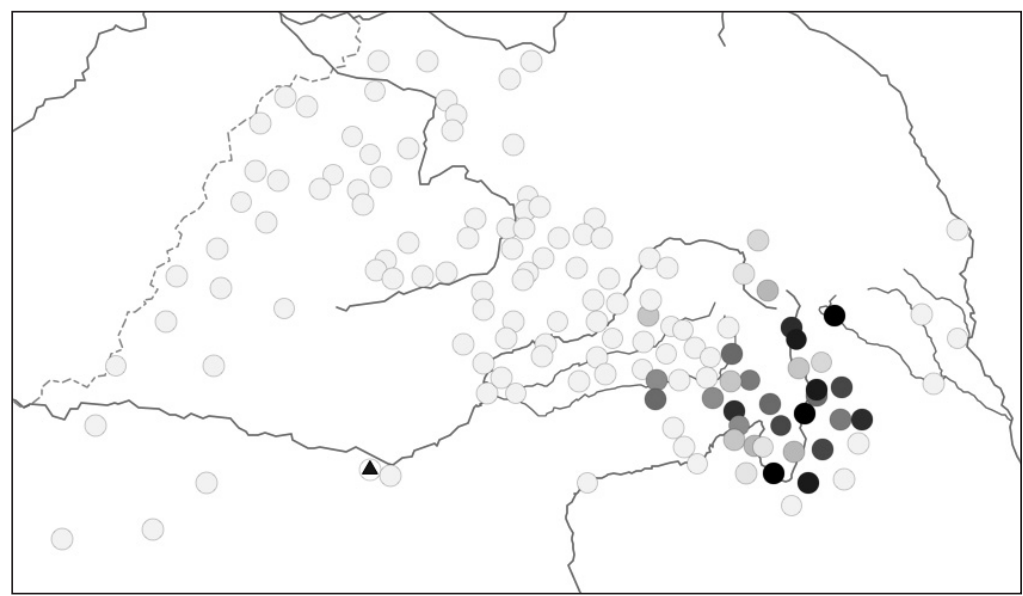




\section{6. térkép}

Lozsád

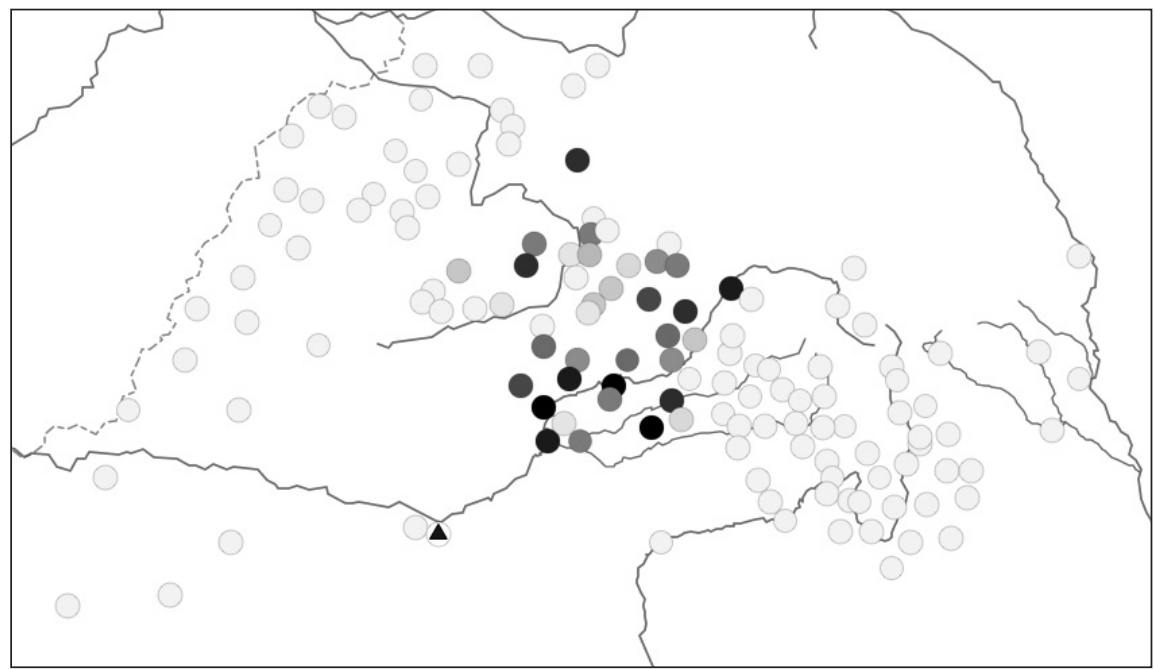

Az eddigi kutatások alapján az udvarhelyszéki vonásokat mutató oltszakadáti nyelvjárás nyelvi hasonlósági súlypontja a dialektometriai térkép szerint inkább nyugatabbra esik, Búnnal és Sárpatakkal mutat leginkább egyezést az atlaszadatok alapján (7. térkép).

\section{7. térkép}

Oltszakadát

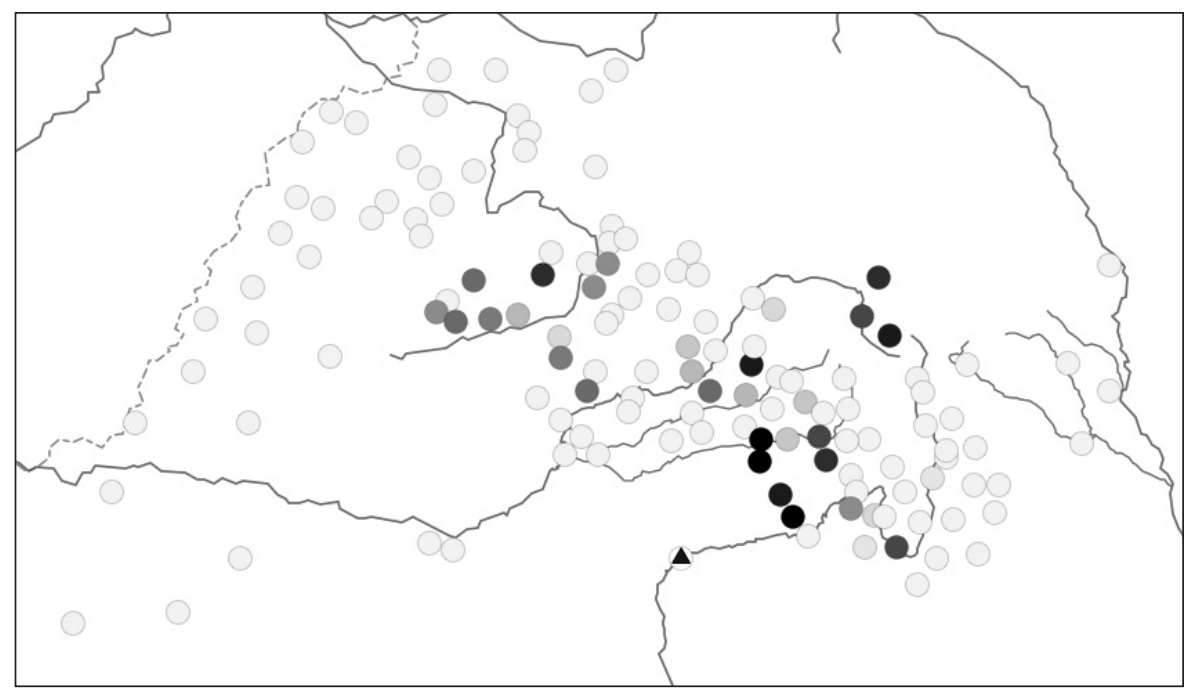

Az Olt mentén fekvő Halmágy a keleti székelységgel, azon belül is Zágonnal mutat leginkább nyelvi hasonlóságot (8. térkép). 


\section{8. térkép}

Halmágy

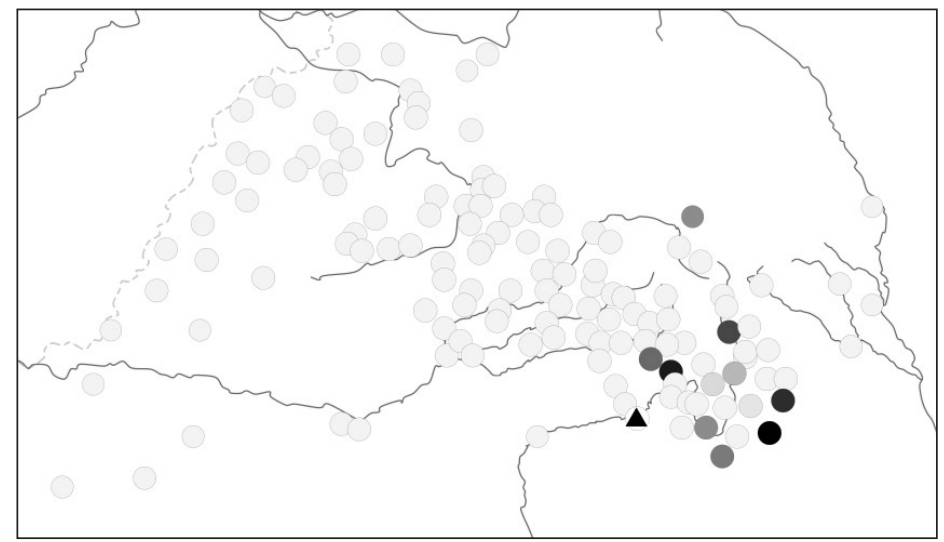

A mezőségi, mára szigethelyzetüvé vált Domokos adatai leginkább Kide és Ördöngösfüzes adataival mutatnak nagyobb nyelvi hasonlóságot, összhangban a korábbi kutatási eredményekkel. A Domokos adataihoz leginkább hasonló harmadik kutatópont a kalotaszegi Magyarkapus (9. térkép).

\section{9. térkép}

Domokos

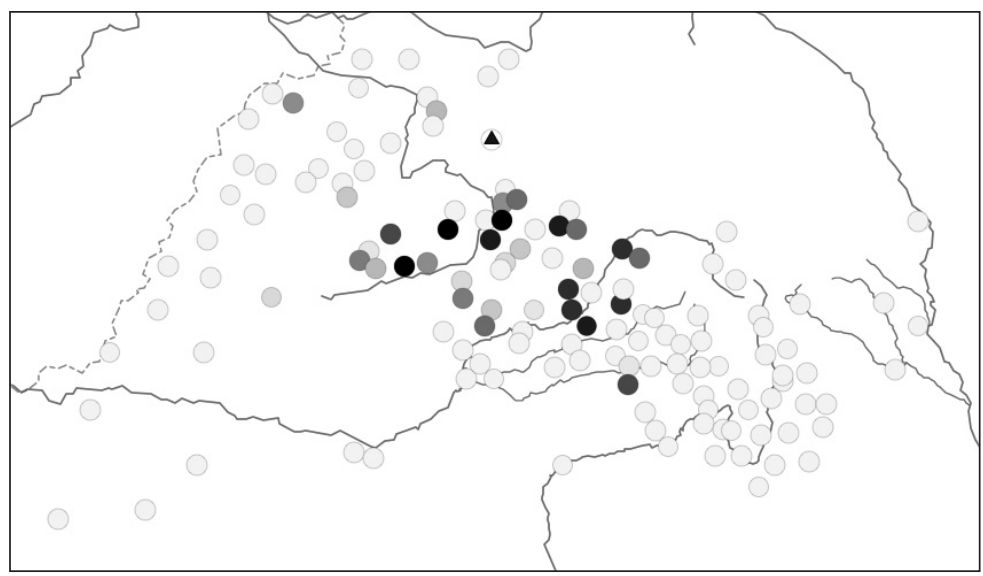

Az érintkező Tisza-Körös vidéki régió hatását is mutató Köröstárkány mezöségi eredetére utal, hogy az RMNyA. kutatópontjai közül, két partiumi kutatópont mellett, Zselykkel is erősebb nyelvi hasonlóságot mutat (10. térkép). Ha azonban megváltoztatjuk az interaktív térkép hátterében lévő mátrixot, és az apró fonetikai különbségekre is érzékeny elemzés helyett a magánhangzók minőségbeli különbségeit figyelmen kívül hagyó (lényegében a lexikai különbségekre összpontosító), 
fonetikailag érzéketlen mátrixot használunk, már csak a partiumi kutatópontok látszanak nagyobb nyelvi hasonlóságot jelző sötétebb árnyalatokkal (11. térkép).

10. térkép

Köröstárkány

(fonetikailag érzékeny mátrix használatával készült nyelvi hasonlósági térkép)

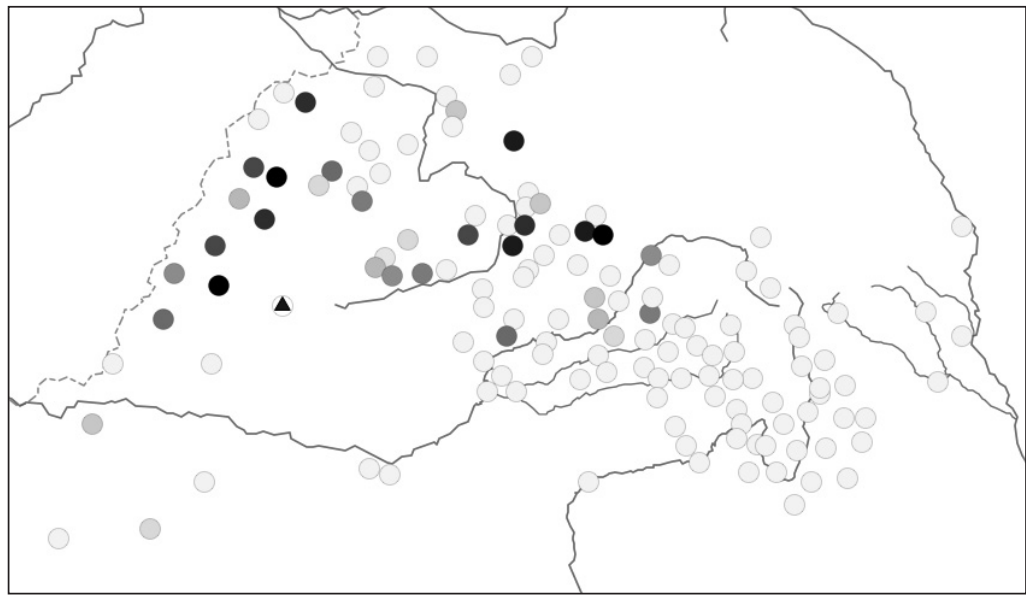

11. térkép

Köröstárkány

(fonetikailag érzéketlen mátrix használatával készült nyelvi hasonlósági térkép)

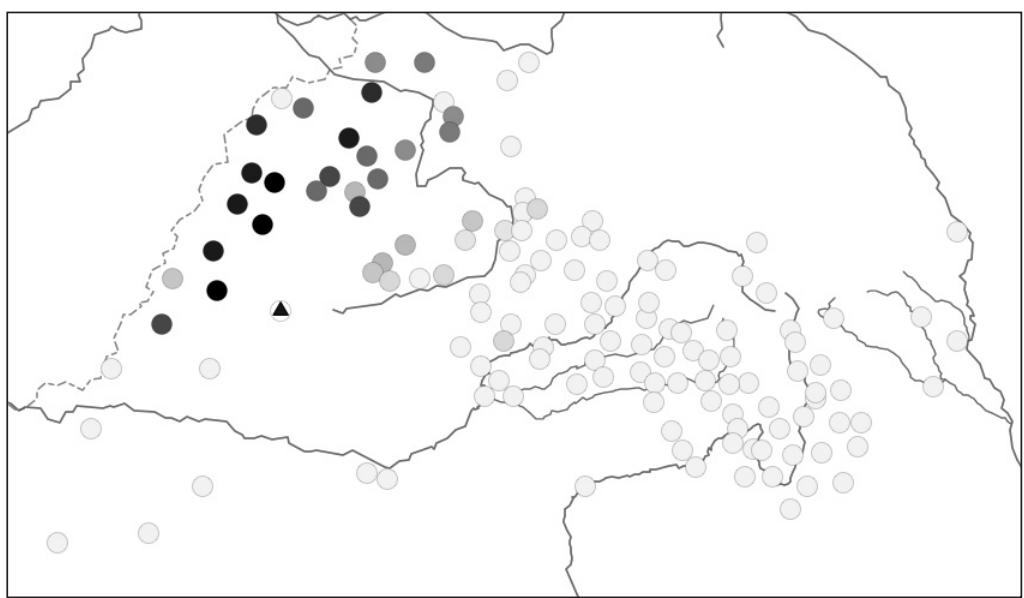

A nyelvi hasonlóságot fonetikailag érzéketlen mátrix alapján vizsgálva a moldvai Szabófalva esetében is egészen megváltozik a térkép. A fonetikailag érzékeny elemzés esetén (1. térkép) sötétszürkével kirajzolódó mezőségi kutatópontok szinte egészen ,eltünnek” a látókörünkből, helyettük a térben közelebb fekvő Székelyföldön találunk sötétebb szürke árnyalatokat (12. térkép). 


\section{2. térkép}

Szabófalva

(fonetikailag érzéketlen mátrix használatával készült nyelvi hasonlósági térkép)

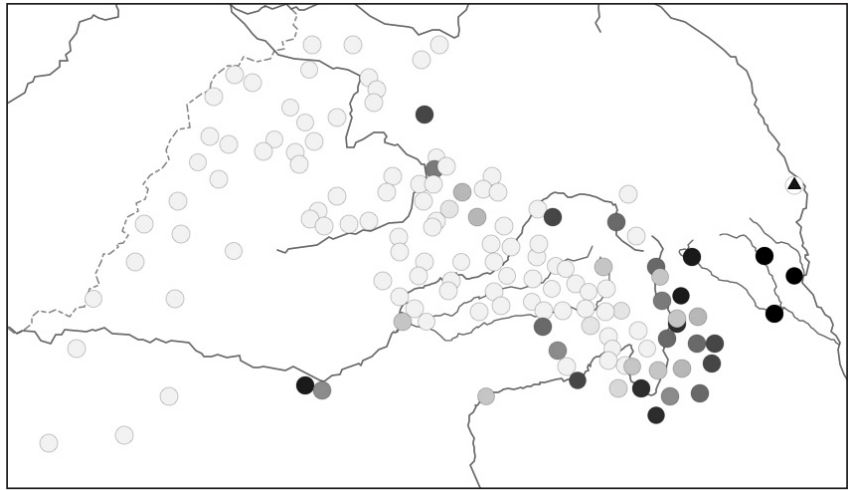

Ahogyan azt a bevezetőben már említettem, az informatizált nyelvjárási adatok, adattárak nem csupán önmagukban elemezhetök a számítógépes dialektológia módszereivel, hanem integrálhatók is egymással. Az azonos címszavú térképlapok adataiból integrált dialektometriai térképet készíthetünk (vö. HEGEDÜS 2004). Így lehetőségünk van arra, hogy megvizsgáljuk a Tisza-Körös vidéki gyökerü Végvár nyelvi hasonlósági viszonyait. Az MNyA. és az RMNyA. 482 integrált térképlapja alapján Végvár adatai legnagyobb arányban Öcsöd adataival mutatnak egyezéseket (13. térkép).

\section{3. térkép}

Végvár

(az MNyA. és az RMNyA. 482 integrált térképlapja alapján)

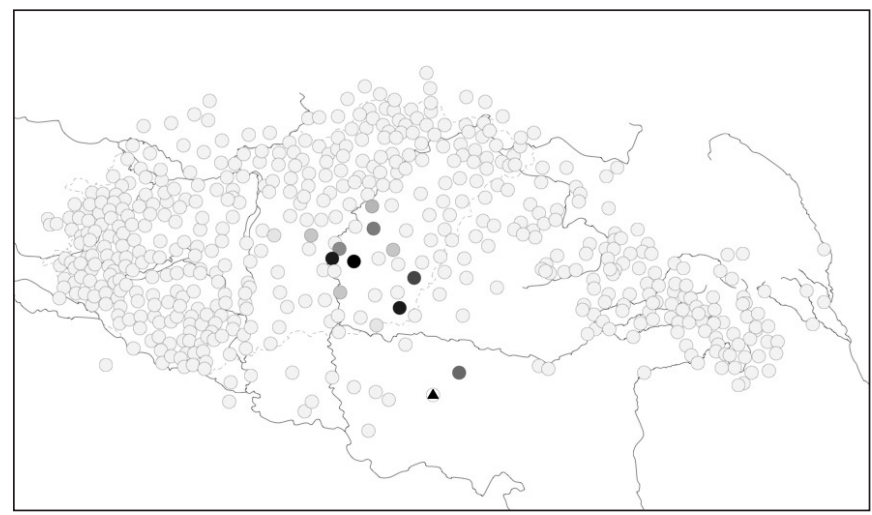

Az elemzésbe bevont 11 RMNyA.-kutatópont feltételezett nyelvjárási kapcsolatait és a dialektometriai elemzés szerint nyelvileg leginkább hasonló kutatópontokat összefoglalóan az 1. táblázatban mutatom be. Szükséges ismét megjegyezni, hogy az általam használt korpuszban mindössze 136 romániai magyar település szerepel, így a nyelvileg hasonlónak mutatkozó települések a legtöbb esetben inkább csak irányokat, mint konkrét helyeket jelölnek számunkra. 


\section{1. táblázat}

A kiválasztott kutatópontok feltételezett nyelvföldrajzi kapcsolatai a szakirodalom (JUHÁSZ 2001, 2004; PÉNTEK 2005) alapján és a dialektometriai térképen legnagyobb nyelvi hasonlóságot mutató kutatópontok

\begin{tabular}{|l|l|l|}
\hline \multicolumn{1}{|c|}{ Kutatópont } & \multicolumn{1}{c|}{ Eredet } & \multicolumn{1}{c|}{ Kapcsolat } \\
\hline Szabófalva & észak-mezőségi & Mezőveresegyháza, Nyíres \\
\hline Bogdánfalva & mezőségi alapú, székelyes & Gyimesbükk, Csíkmenaság \\
\hline Pusztina & keleti székely & $\begin{array}{l}\text { Gyimesbükk, Csíklázárfalva, } \\
\text { Kézdialmás }\end{array}$ \\
\hline Diószeg & keleti székely & Kézdialmás \\
\hline Csernakeresztúr & bukovinai székely & Sepsibükszád, Gyimesbükk \\
\hline Lozsád & dél-mezőségi & Magyarsáros, Miriszló \\
\hline Oltszakadát & udvarhelyszéki & Bún, Sárpatak \\
\hline Halmágy & keleti székely & Zágon \\
\hline Domokos & mezőségi & Kide, Ördöngösfüzes \\
\hline Köröstárkány & mezőségi & Zselyk, Szék \\
\hline Végvár & Tisza-Körös vidéki & Öcsöd \\
\hline
\end{tabular}

5. Tanulságok. Az itt bemutatott dialektometriai térképek tanulságait öszszefoglaló 1. táblázat alapján elmondhatjuk, hogy a dialektometria kifejezetten alkalmas módszer lehet a szigetszerü helyzetben lévő (illetve moldvai) kutatópontok nyelvi kapcsolatainak vizsgálatához, amely sokszor határozottan megerösíti, egyben tovább pontosítja a szóban forgó beszélöközösség eredetéről vagy nyelvi kötődéseiröl már rendelkezésre álló ismereteket, esetleg további elképzelések teszteléséhez mutathat irányt. A térképes kimutatások segíthetnek tehát a nyelvjárásszigetek nyelvi kapcsolatrendszerének pontosabb feltárásában.

Noha számos esetben nagyfokú dialektometriai hasonlóságot találunk a feltételezett lakosságkibocsátó hely és a kirajzás között, fontos világosan leszögezni, hogy a földrajzi távolság ellenére megmutatkozó jelentős nyelvi hasonlóság nem értelmezhető automatikusan településtörténeti kapcsolatként.

A kiejtésbeli különbségeket különböző mértékben figyelembe vevő mátrixok feltehetően a nyelvi rendszer különböző rétegeiben mutatkozó hasonlóság kimutatására alkalmasak. A fonetikailag érzékeny elemzéssel szemben az adatok lejegyzésének egyszerüsítésén alapuló eljárás inkább csak a lexikai különbségekre és hasonlóságokra érzékeny, így az ilyen dialektometriai térképeken a nyelv(járás) szigetek már nem a feltételezett kibocsátó hellyel (vagy annak környezetével), hanem rendszerint a hozzájuk térben legközelebb eső kutatópontokkal mutatnak nagyobb nyelvi hasonlóságot. A különböző mátrixok által kirajzolt térképek összevetése alapján úgy látszik, leginkább a fonetikailag érzékeny elemzés alkalmas a lehetséges nyelvföldrajzi kapcsolatok kimutatására térben távoli kutatópontok között. Ez a megállapítás összhangban áll azzal a feltételezéssel, hogy a nyelvjárásközi öszszevető vizsgálatokban a hangtannak van kitüntetett szerepe (vö. VARGHA 2015a). 
Az azonos eljárással, azonos kódrendszer szerint informatizált nyelvjárási adatok integrálhatók, integráltan elemezhetők. Az integrált dialektometriai térképek segítségével a különböző adattárak kutatópontjai közti nyelvi hasonlóság is vizsgálható.

Kulcsszók: dialektometria, kvantitatív nyelvföldrajz, nyelvjárásszigetek, nyelvi hasonlóság, A romániai magyar nyelvjárások atlasza.

\section{Hivatkozott irodalom}

BALOGH LAJOS 2001. A nyelvjárásszigetek. In: KISS JENŐ szerk., Magyar dialektológia. Osiris Kiadó, Budapest. 316-324.

BALOGH LAJOS - KISS GÁBOR 1992. A magyar nyelvjárások atlaszának számítógépes feldolgozása. In: KONTRA MIKLÓS szerk., Társadalmi és területi változatok a magyar nyelvben. MTA Nyelvtudományi Intézet, Budapest. 5-17.

BODÓ CSANÁD 2007. A moldvai magyar nyelvjárások román kölcsönszórétegének területisége. In: BENÖ ATTILA - FAZAKAS EMESE - SZILÁGYI N. SÁNDOR szerk., Nyelvek és nyelvváltozatok. Köszöntö kötet Péntek János tiszteletére 1-2. Anyanyelvápolók Erdélyi Szövetsége Kiadó, Kolozsvár. 1: 160-174.

Bodó CSANÁd - VARgha FrUZsina SÁRA 2008. Régi nyelvatlaszok - új módszerek. Magyar Nyelv 104: 335-351.

Chambers, Jack -Trudgill, Peter 1998. Dialectology. 2nd edition. Cambridge University Press, Cambridge.

GoEBL, HANS 2006. Recent Advances in Salzburg Dialectometry. Literary and Linguistic Computing 21: 411-435. http://dx.doi.org/10.1093/llc/fq1042

HeERINGA, WilBert 2004. Measuring Dialect Pronunciation Differences using Levenshtein Distance. Groningen Dissertations in Linguistics 46. K. n., Groningen.

HeEringa, Wilbert - Nerbonne, John 2013. Dialectometry. In: HinSKens, Frans TAELDEMAN, JOHAN eds., Language and Space. An International Handbook of Linguistic Variation, Volume III. Dutch. Walter de Gruyter, Berlin - New York. 624-646.

HEGEDŰS ANDREA 2004. Az egyesített nyelvatlaszok jelentőségéröl. In: P. LAKATOS ILONAT. KÁROLYI MARGIT szerk., Nyelvvesztés, nyelvjárásvesztés, nyelvcsere. Segédkönyvek a nyelvészet tanulmányozásához 32. Tinta Könyvkiadó, Budapest. 178-181.

JuHÁSz DEZSÖ 2001. A magyar nyelvjárások területi egységei. In: KISS JENÖ szerk., Magyar dialektológia. Osiris Kiadó, Budapest. 262-315.

JUHÁSZ DEZsÖ 2004. Az északi csángók eredetéről „A romániai magyar nyelvjárások atlasza" tükrében. In: P. LAKATOS ILONA - T. KÁROLYI MARGIT szerk., Nyelvvesztés, nyelvjárásvesztés, nyelvcsere. Segédkönyvek a nyelvészet tanulmányozásához 32. Tinta Könyvkiadó, Budapest. 163-174.

JuHÁsz Dezső 2011. A magyar nyitódó kettőshangzók történetéről a tér és idő dimenziójában. In: BAKRÓ-NAGY MARIANNE - FORGÁCS TAMÁs szerk., A nyelvtörténeti kutatások újabb eredményei VI. Szegedi Tudományegyetem Magyar Nyelvészeti Tanszék, Szeged. 123-128.

PÉNTEK JÁNOS 2005. Magyar nyelv- és nyelvjárásszigetek Romániában. Magyar Nyelv 101: 406-413. 
SÉGUY, JEAN 1973. La dialectométrie dans l'atlas linguistique de la Gascogne. Revue de linguistique romane 37: 1-24.

VARGHA FRUZSINA SÁRA 2007a. Állatok kicsinyeinek megnevezése a keleti magyar nyelvjárásokban. In: HofFMANN ISTVÁN - JUHÁSZ DEZSÖ szerk., Nyelvi identitás és a nyelv dimenziói. Nemzetközi Magyarságtudományi Társaság, Debrecen-Budapest. 237-248.

VARGHA FRUZSINA SÁRA 2007b. Nyelvi változók a Magyar nyelvjárások atlasza hangfelvételeiben. In: GuTtMAnN Miklós - MolnÁR Zoltán szerk., V. Dialektológiai Szimpozion. Szombathely, 2007. augusztus 22-24. Berzsenyi Dániel Főiskola, Szombathely. 279-288.

VARGHA FRUZSINA SÁRA - VÉKÁS DOMOKOS 2009. Magyar nyelvjárási adattárak vizsgálata interaktív dialektometriai térképekkel. Előadás a Magyar Nyelvtudományi Társaság felolvasóülésén, 2009. március 24-én. http://bihalbocs.hu/eloadas/dialektometria_[-] 20090324.pdf (2016. 07. 07.)

VARGHA FRUZSINA SÁRA 2013. A hangzó adat szerepe a magyar dialektológiában. In: SzOTÁK SzILVIA - VARGHA FRUZSINA SÁRA szerk., Változó nyelv, nyelvváltozatok, területiség. A VII. Hungarológiai Kongresszus nyelvészeti tanulmányai. Egyetemi Műhely Kiadó - Bolyai Társaság, Kolozsvár. 194-204.

VARGHA FrUZSINA SÁRA 2015a. Atlaszintegrálás és kvantitatív adatelemzés. In: BÁRTH M. JÁNOS - BODÓ CSANÁD - KoCsIS ZSUZSANNA szerk., A nyelv dimenziói. Tanulmányok Juhász Dezsö tiszteletére. ELTE BTK, Budapest. 242-249.

VARGHA FrUZSINA SÁRA 2015b. Lexikai, fonológiai, fonetikai stabilitás (és relevancia) a magyar nyelvjárásokban. In: É. KISS KATALIN - HEGEDÜS ATTILA - PINTÉR LILLA szerk., Nyelvelmélet és dialektológia 3. PPKE BTK Elméleti Nyelvészeti Tanszék Magyar Nyelvészeti Tanszék, Budapest-Piliscsaba. 243-261.

VÉKÁS DOMOKOS 2007. Számítógépes dialektológia. In: GUTTMANN MiKLÓS - MOLNÁR Zoltán szerk., V. Dialektológiai Szimpozion. Szombathely, 2007. augusztus 22-24. Berzsenyi Dániel Főiskola, Szombathely. 289-293.

\section{A quantitative study in linguistic geography based on informatised maps of The Atlas of Hungarian Dialects in Romania}

In a series of interrelated computational dialectology projects of the past ten years, computerised (appropriately digitised and fit for quantitative analysis) versions of The Atlas of Hungarian Dialects and several regional atlases have been produced. This paper investigates the applicability of dialectometric analyses based on computerised volumes of The Atlas of Hungarian Dialects in Romania for the study of the origins of dialect islands and those of Hungarian settlements in Moldova. The results show that dialectometry as an objective research method may be appropriate for the confirmation and refinement of results of earlier analyses following other methods; that is, it can be put to good use in exploring centuries-old linguistic relations.

Keywords: dialectometry, quantitative linguistic geography, dialect enclaves, linguistic similarity, The Atlas of Hungarian Dialects in Romania. 